\title{
Effects of Pineapple Juice and Ginger Drink for Relieving Primary Dysmenorrhea Pain among Adolescents
}

\author{
Dita Wrisnijati'), Budiyanti Wiboworini²), Sugiarto2) \\ ${ }^{1)}$ Masters Program in Nutrition, Universitas Sebelas Maret \\ ${ }^{2)}$ Faculty of Medicine, Universitas Sebelas Maret
}

\begin{abstract}
Background: Primary dysmenorrhea is characterized by low abdominal pain occurring during menstruation. It is negatively impact on all aspects of life of adolescents such as increased school absteeinsm, emotional disorders, impaired social interaction and productivity. The herbal drink which they can self-prepared is common choice as home remedies to relieve the pain. This study aimed to examine the effect of pineapple juice and ginger drink in providing pain relief to the adolescent with primary dysmenorrhea.

Subjects and Method: This was a randomized trial study conducted at three high schools in Surakarta, Central Java, Indonesia, from January to April 2018. A sample of 39 female students aged 15-17 years was selected for this study, divided into three groups. The treatment was given for 3 days from first day of menstruation for 3 menstruation cycles. The pain score were measured by numeric rating scale (NRS). The data were analyzed by Mann-Whitney.

Results: Pain score in pineapple juice group (mean $=2.25 ; \mathrm{SD}=1.79)$ and ginger drink group (mean= 3.63; $\mathrm{SD}=2.02)$ were lower than control group (mean= 5.64; $\mathrm{SD}=1.25$ ) and it was statistically significant.

Conclusion: Pineapple juice and ginger drink effective to reduce pain of primary dysmenorrhea among female adolescent.
\end{abstract}

Keywords: Dysmenorrhea, pain, pineapple juice, ginger drink, female adolescents

\section{Correspondence:}

Dita Wrisnijati. Masters Program in Nutrition, Universitas Sebelas Maret. Jl. Ir. Sutami 36A, Surakarta 57126, Central Java. E-mail: ditawrisnijati@gmail.com. Mobile: (62)85742916542.

\begin{tabular}{l} 
BACKGROUND \\
\hline Adolescence is the transitional phase \\
between childhood and adulthood and cha- \\
racterized by physical growth, psychological \\
changes, and secondary sexual changes. \\
The most striking change is the onset of \\
menstruation (Santoro and Neal-Perry, \\
2010). After menarche, the most common \\
gynaecological disorders that may encoun- \\
ter is dysmenorrhea (Jenabi, 2013). Dysme- \\
norrhea is a common gynaecological dis- \\
order with painful cramps of uterin origin. \\
The term dysmenorrhea is derived from the \\
Greek words dys (difficult, pain, abnormal), \\
mena (month), and reha (flow) (Madhubala \\
and Jyoti, 2012). It can be either primary \\
(absence of an identifiable pathological
\end{tabular}

condition) or secondary (due to pathology condition such as endometriosis). Primary dysmenorrhea is highly prevalent that estimated occurs in $45-90 \%$ of productive women (Bernardi et al., 2017). It usually begins before or at the start of menstrualtion, and continue for 2-3 days (Wallace et al., 2010). The pain felt mainly in the lower abdomen, but it may radiate to the back and along the thighs. In a severe case, it usually accompanied by some other symptoms such as nausea, vomiting, diarrhea, headache, fatigue, dizziness, decreased concentration, loss of appetite, insomnia, to loss of consciousness (Fatima et al., 2016). The consequences not only affect reduces productivity such as school or works absen- 
teeism, but also effects of quality of life because it is decreased academic performance, lead depressed mood, lethargy, and disruption of social (Al-Asadi and Abdul Quadir, 2013).

Primary dysmenorrhea well-recognized by increasing of prostaglandin (PGs). Prostaglandins have a role inducing uterine contraction, decreasing uterine blood flow, increasing peripheral nerve hypersensitivity resulting in pain and cramps. Treatment for primary dysmenorrhea could be a selfmedication such as non-pharmacological home remedies (warm beverages, heat application, back massage, low-fat diet, lifestyle modification, and herbal treatment), taking over-the-counter drugs or seeking medical advice such as take prescription analgesics and hormonal contraceptives. Non-steroidal anti-inflammation drugs (NSAIDs) and antispasmodics are commonly used drugs. NSAIDs such as ibuprofen, mefenamic acid, naproxen, ketoprofen, celecoxib, and diclofenac are proven to be effective by inhibiting cyclooxygenase leading to the reduction of prostaglandins secretion. Hormonal therapy in the form of oral contraceptive usually used for patients with lack of response to NSAIDs. Despite it is considerable, but the failure rate is still high, the pain relief inadequate for some women, and the side effects not be well tolerated (Ramya et al., 2014). Therefore, over the last 15 to 20 years, there has been an increase in the use of herbal medicine which they can self-prepared as home remedies (Wong et al., 2009).

The herbal products used for the treatment of primary dysmenorrhea throughout the world vary. In Indonesia, ginger root (Zingibers officinale) is wellknown herbal products common used as traditional medicine, spices and drink to warm the body. Study by Chen et al. (2016) found that ginger has been proven as anti- inflammatory agent and has therapeutic effect to relieves the pain of dysmenorrhea. This benefits comes from gingerol and 6shogaol as active component of ginger. Gingerol works to inhibit the formation of cyclooxygenase (COX) enzymes and prostaglandin synthesis. This mechanism is similar with action of non-steroidal anti inflammation drugs (NSAIDs) such as ibuprofen and naproxen which also work by inhibits the acivity of COX-1 and COX-2 enzymes (Ozgoli et al., 2009).

Besides ginger, pineapple fruit (Ananas comosus (L.)) is also well-known fruit used as a meat tenderizer and traditional remedy for several ailments related inflammation. Therapeutic benefits from pineapple fruits are attributed to bromelain. Bromelain is an extract obtained from pineapple that belongs to a group of protein-digesting enzymes and a protease inhibitor. A wide range of therapeutic benefit have been claimed for bromelain, such as accelerates post-traumatic wound healing (Hirche et al., 2017), relieves joint pain due to arthritis and rheumatic (Jayachandran and Kobre, 2017), immunemodulator with anti-tumor and anti-cancer activity (Mohammed et al., 2017), antiplaque and anti-gingivitis (Tadikonda et al., 2017), antioxidant (Rodrigues et al., 2017), anti-ulcer (Sowjanya et al., 2016), antibiotics in cases of pneumonia, bronchitis, and sinusitis (Dighe et al., 2010) and potentially as pain reliever and analgesic in several inflammatory reactions (Singh et al., 2016). The anti-inflammatory and analgesic activity of bromelain are proven to be effective leading reduction of prostaglandin production by inhibits cyclooxygenase pathway (Conteras et al., 2008). With this mechanism, bromelain could be considered as potential phytomedical or herbal remedies for relieves the pain of primary dysmenorrhea. This present study was to 
Indonesian Journal of Medicine (2019), 4(2): 96-104

https://doi.org/10.26911/theijmed.2019.04.02.03

assess the effectiveness of pineapple juice and ginger drink in providing pain relief to the adolescent with primary dysmenorrhea.

\section{SUBJECTS AND METHOD \\ 1. Study Design \\ This was a randomized control trial con- ducted in Senior High Schools in Surakarta, Central Java.}

\section{Study Sample}

A sample of 39 female students aged 15-17 years was selected for this study by simple random sampling, divided into three groups. The treatment was given for 3 days from first day of menstruation for 3 menstruation cycles. The exclusion criteria included students who had mild dysmenorrhea, taking either home remedies or oral analgesics for relieves the pain, smoking, drink alcohol, have a history gynaecological disorders or under medical treatment.

\section{Study Variables}

The dependent variable was pain of dysmenorrhea. The independent variables were the administration of pineapple juice and ginger drink.

\section{Study Instruments}

Pain was measured by Numeric Rating Scale (NRS). Data about sosio-demoghrapics and menstrual pattern were collected by questionnaire. BMI was calculated using height (meter) / weight ${ }^{2}(\mathrm{~kg})$.

The pineapple juice and ginger drink was prepared freshly. The pineapple juice made by certain dose, $3.75 \mathrm{~g} / \mathrm{kgBW}$ of fresh pineapple fruits (Ananas comosus (L.)) var. Cayenne, 10 grams of sugar, and $200 \mathrm{ml}$ water then it blends until smooth, and the ginger drink made by boiling 15 grams of ginger (Zingibers officinale) var. amarum and 10 grams palm sugar with $500 \mathrm{ml}$ water during 15 minutes until the water volume become $200 \mathrm{ml}$.

\section{Data Analysis}

The socio-demographic and menstrual characteristic described with descriptive analysis. Test the normality of data using Saphiro-Wilk. Differences in mean pain score before and after intervention in each group using Wilcoxon test. Mann-Whitney (Post-hoc) test was used to determine the differrence in mean pain score between groups and see which treatment groups were different.

\section{Research Ethics}

This study has been approved by the Research Ethics Committee of Dr. Moewardi Hospital and Faculty of Medicine Universitas Sebelas Maret Surakarta with ethical number 1.160/XII/HREC/2017. We obtained written informed consent from the study subjects.

\section{RESULTS}

The study involved a total of 39 subjects. Two subjects from pineapple juice group discontinued the trial due to had their menstruation when they went to Bali to study tour, two subjects from ginger drink group discontinued due to took oral analgesics for relieved their pain, and two subjects from control group discontinued the trial because rejected to continued this research project any longer, so the subjects analyzed were 33 subjects. No subjects in the trial had any complication after had been treated.

The mean age of the subjects was $15.67 \pm 0.65$ years. Most of them (57.6\%) had a normal nutritional status, and $42.4 \%$ had malnutrition with BMI mean was $20.57 \pm 0.74 \mathrm{~kg} / \mathrm{m} 2$. Most of them (90.9\%) hailed from the upper middle class of socioeconomic status. The study subject had attained menarche ranging from 9-15 years with mean $12.18 \pm 0.26$ years. Most of them (93.9\%) had a family history of dysmenorrhea. Around 25 subjects (75.8\%) had 
the length of the cycle of 25-32 days and 8 subjects (24.2\%) had irregular cycles. Majority of the subjects (90.9\%), had the menstrual flow of 4-7 days duration. About half of the subject (51.5\%) suffered a moderate dysmenorrhea, and the other half suffered a severe dysmenorrhea. There were no significant differences between the two groups concerning baseline characteristics including the socio-demographic or menstrual pattern (Table 1).

Table 1. Socio-Demographic and Menstrual Characteristics Subjects

\begin{tabular}{|c|c|c|c|c|c|c|c|c|}
\hline \multirow[t]{2}{*}{ Characteristics } & \multicolumn{2}{|c|}{$\begin{array}{c}\text { Pineapple juice } \\
\text { group }\end{array}$} & \multicolumn{2}{|c|}{$\begin{array}{c}\text { Ginger } \\
\text { drink group }\end{array}$} & \multicolumn{2}{|c|}{$\begin{array}{l}\text { Control } \\
\text { group }\end{array}$} & \multicolumn{2}{|c|}{ Total } \\
\hline & $\mathbf{n}$ & $\%$ & $\mathbf{n}$ & $\%$ & $\mathbf{n}$ & $\%$ & $\mathbf{n}$ & $\%$ \\
\hline \multicolumn{9}{|l|}{ Age } \\
\hline 15 years & 4 & 36.4 & 5 & $45 \cdot 5$ & 5 & $45 \cdot 5$ & 14 & 42.4 \\
\hline 16 years & 6 & $54 \cdot 5$ & 5 & $45 \cdot 5$ & 5 & $45 \cdot 5$ & 16 & 48.5 \\
\hline 17 years & 1 & 9.1 & 1 & 9.1 & 1 & 9.1 & 3 & 9.1 \\
\hline \multicolumn{9}{|l|}{ Grade of school } \\
\hline $\mathrm{X}$ & 4 & 36.4 & 5 & $45 \cdot 5$ & 5 & $45 \cdot 5$ & 14 & 42.4 \\
\hline XI & 7 & 63.6 & 6 & 54.5 & 6 & $54 \cdot 5$ & 19 & 57.6 \\
\hline \multicolumn{9}{|l|}{ BMI (kg/m²) } \\
\hline Underweight & 3 & $27 \cdot 3$ & 3 & $27 \cdot 3$ & 3 & $27 \cdot 3$ & 9 & $27 \cdot 3$ \\
\hline Normal & 6 & $54 \cdot 5$ & 7 & 63.6 & 6 & 54.5 & 19 & 57.6 \\
\hline Overweight & 2 & 18.2 & 1 & 9.1 & 2 & 18.2 & 5 & 15.1 \\
\hline \multicolumn{9}{|l|}{ Family income } \\
\hline High & 10 & 81.8 & 9 & 81.8 & 11 & 100 & 30 & 90.9 \\
\hline Low & 1 & 18.2 & 2 & 18.2 & O & $\mathrm{O}$ & 3 & 9.1 \\
\hline \multicolumn{9}{|l|}{ Age at Menarche } \\
\hline$<12$ years & 5 & $45 \cdot 5$ & 5 & $45 \cdot 5$ & 5 & $45 \cdot 5$ & 15 & $45 \cdot 5$ \\
\hline 12 - 14 years & 6 & 54.5 & 5 & 45.5 & 5 & $45 \cdot 5$ & 16 & 48.5 \\
\hline$>14$ years & - & - & 1 & 9.0 & 1 & 9.0 & 2 & 6.0 \\
\hline \multicolumn{9}{|l|}{$\begin{array}{l}\text { Family history of } \\
\text { dysmenorrhea }\end{array}$} \\
\hline Yes & 11 & 100 & 10 & 90.9 & 10 & 90.9 & 31 & 93.9 \\
\hline No & - & - & 1 & 9.1 & 1 & 9.1 & 2 & 6.1 \\
\hline \multicolumn{9}{|l|}{ Menstrual cycle duration } \\
\hline$<25$ days & 2 & 18.2 & 3 & 23.7 & 2 & 18.2 & 7 & 21.2 \\
\hline $25-32$ days & 9 & 81.8 & 7 & 63.6 & 9 & 81.8 & 25 & 75.8 \\
\hline$>32$ days & - & - & 1 & 9.1 & - & - & 1 & 3.0 \\
\hline \multicolumn{9}{|l|}{$\begin{array}{l}\text { Menstrual bleeding } \\
\text { duration }\end{array}$} \\
\hline 4-7 days & 10 & 90.9 & 10 & 90.9 & 10 & 90.9 & 30 & 90.9 \\
\hline$>7$ days & 1 & 9.1 & 1 & 9.1 & 1 & 9.1 & 3 & 9.1 \\
\hline \multicolumn{9}{|c|}{ Severity of Dysmenorrhea } \\
\hline Moderate Pain & 5 & $45 \cdot 5$ & 6 & $54 \cdot 5$ & 6 & 54.5 & 17 & 51.5 \\
\hline Severe Pain & 6 & 54.5 & 5 & 45.5 & 5 & $45 \cdot 5$ & 16 & 48.5 \\
\hline
\end{tabular}

Table 2 shows that the greatest decreased of before-after treatment score was in the pineapple juice group. The value of $\mathrm{p}<0.001$ and $\mathrm{p}=0.008(\mathrm{p}<0.05)$ means that there were a significant difference in pain score in the three groups, but in the control group, the pain score after treatment was higher than before treatment score. It can be concluded that in the control group, the pain score was increased.

Post hoc test showed that there were significant differences in pain score between pineapple juice group with control group $(\mathrm{p}<0.001)$, between ginger drink group and control group $(\mathrm{p}=0.001)$, and between pineapple juice group with ginger drink group $(\mathrm{p}<0.008)$. This means admi- 
nistration of both pineapple juice and ginger drink are effective to providing pain relief, but pineapple juice was found had a greater effect to relieving pain of primary dysmenorrhea among adolescent (Table 2).

Table 2. Pain Scores Between Groups

\begin{tabular}{|c|c|c|c|c|c|c|c|}
\hline $\begin{array}{l}\text { Type of } \\
\text { treatment }\end{array}$ & $\begin{array}{c}\text { Before } \\
\text { treatmen } \\
\text { t (Mean } \pm \\
\text { SD) }\end{array}$ & $\begin{array}{c}\text { After } \\
\text { treatment } \\
\text { (Mean } \pm \\
\text { SD) }\end{array}$ & $\begin{array}{c}\Delta \text { After- } \\
\text { Before } \\
\text { (Mean } \pm \\
\text { SD) }\end{array}$ & $\mathbf{p}^{\mathbf{a}}$ & Post hoc & $\begin{array}{c}\Delta \text { After } \\
\text { Treatment } \\
\text { between } \\
\text { groups } \\
(\text { Mean } \pm \text { SD) } \\
\end{array}$ & $\mathbf{p}^{\mathbf{b}}$ \\
\hline $\begin{array}{l}\text { Pineapple } \\
\text { juice }(n=11)\end{array}$ & $5.24 \pm 1.95$ & $2.25 \pm 1.79$ & $2.99 \pm 1.87$ & $<0.001$ & $\begin{array}{l}\text { Pineapple } \\
\text { juice vs } \\
\text { control }\end{array}$ & $3.39 \pm 0.54$ & $<0.001$ \\
\hline $\begin{array}{l}\text { Ginger drink } \\
(\mathbf{n}=11)\end{array}$ & $5 \cdot 55 \pm 1.68$ & $3.63 \pm 2.02$ & $1.92 \pm 1.85$ & $<0.001$ & $\begin{array}{l}\text { Ginger } \\
\text { drink vs } \\
\text { control }\end{array}$ & $2.01 \pm 0.77$ & $<0.001$ \\
\hline $\begin{array}{l}\text { Control } \\
(n=11)\end{array}$ & $5.44 \pm 1.07$ & $5.64 \pm 1.25$ & $0.2 \pm 1.16$ & 0.008 & $\begin{array}{l}\text { Pineapple } \\
\text { juice vs } \\
\text { ginger } \\
\text { drink }\end{array}$ & $1.38 \pm 0.23$ & $<0.001$ \\
\hline
\end{tabular}

Notes:

${ }^{a} \mathrm{p}$-value for Wilcoxon's test

${ }^{b}$ p-value for Mann-Whitney's (post hoc) test

\section{DISCUSSION}

The administration of pineapple juice and ginger drink in the 3 days after the onset of menstrual during 3 menstruation cycle can decrease the pain score of dysmenorrhea among adolescents. The dependent analysis showed that pineapple juice and ginger drink could decrease the pain score for about $2.99 \pm 1.87,1.92 \pm 1.85$, respectively and statistically significant $(\mathrm{p}=0.001)$. The result of the present study supported by the study by Hidayat (2010) which conducted in wistar mice that found bromelain on pineapple juice has $56.82 \%$ anti-inflammatory effect and $58.90 \%$ analgesic effects. Another study conducted a study in vivo and in vitro to endometriosis cases related to dysmenorrhea and pelvic pain. This study concluded that bromelain was an effective treatment for endometriosis that may have potential therapeutic uses in the prevention and treatment of the patient (Agostinis et al., 2014).

As long as author's findings, there was no specific research that assesses the potential of bromelain in pineapple juice for relieving pain of primary dysmenorrhea, but study about bromelain commonly concluded have potential therapeutic effects in either acute or chronic inflammatory disease (Muller et al., 2013; Bolten et al., 2015; Singh et al., 2016; Rathnavelu et al., 2016; Zhou et al., 2017; Sahbaz et al., 2015). The effect of pineapple juice on relieving the pain of dysmenorrhea may be contribute to bromelain content on pineapple fruit. Onken et al. (2008) showed that bromelain contain on pineapple fruits has an anti-inflammatory effect and analgesic activity because acts as inhibitor that against Phospholipase $\mathrm{A}_{2}$ (Pla2) activity. Pla2 has been identified contribute to the initiation of inflammation which subsequently induces the production of arachidonic acid (Onken et al., 2008). Arachidonic acid is metabolized from either the cyclooxygenase or lipooxygenase enzymetic pathway for the production of prostaglandins and leukotrienes, which are primarily in the inflammatory pathway (Tap, 2018). 
Muhammad and Ahmad (2017) showed that bromelain acts lowering plasmakinin (bradykinin) at inflammatory site, lowering prostaglandin E2 (PGE2) levels, increases platelet cyclic adenosine monophosphate (cAMP) levels thus increasing prostaglandin I2 (PGI2) which acts as vasodilator at inflammation site. However, bromelain inhibits the production of prostaglandin F2 $\alpha$ (PGF2 $\alpha$ ) and Thromboxane A2 (TXA2) by inhibits cyclooxygenase-2 (COX-2) pathway (Bhui et al., 2009). Bromelain was considerable to activated immune system due to it leads to the formation of inflamemation mediator such as (IL)-1 $\beta$, IL-6, interferon (INF)- $\gamma$ to accelerated homeostasis and control the inflammation (Pavan et al., 2012).

Consumption of ginger drink can decreased the pain score of primary dysmenorrhea (Latha and Venketesan, 2016; Leelavathi and Hemavaty, 2015 ; Rahnama et al., 2012). Ginger has been proven as an herbal drug for treatment of dysmenorrhea due to have anti-inflammatory properties and acts as COX-2 inhibitors similar to NSAIDs such as mefenamic acid (Shirvani et al., 2014). To explain the effects of ginger drink on reducing pain score of dysmenorrhea, it has been reported that ginger root contains an active compound such as gingerol and 6-shogaol which considered as anti-inflammatory and analgesics agent (Ali et al., 2008). Pre-clinical research explains that gingerol and 6-shogaol inhibits the metabolism of arachidonic acid and prostaglandin through the COX-2 pathway. In addition, gingerol and 6-shogaol also inhibits lipopolysaccharide (LPS) which induces PGE2 (Dugasani et al., 2010) and NO synthesis (Jung et al., 2009). Genetically, gingerol and 6-shogaol also has the ability to inhibit the coding of genes that induces pro-inflammatory cytokines synthesis and secreted in the inflammatory area (Pan et al., 2008).

Pineapple juice and ginger drink also contains ascorbic acid which acts as antioxidant and anti-inflammatory agent. It has been widely studied that ascorbic acid was a potent free radical scavenger, and protecting cells against oxidative damage caused by ROS. It is closely associated because in several chronic and acute inflammation and oxidative stress would lead to its depletion and worse the inflamemation (Sorice et al., 2014). However, the inhibition of prostaglandin levels during menstruation was the key mechanism for pineapple juice and ginger drink's effect on pain of dysmenorrhea in this study.

Limitation of this study was did not analyze the intake of other nutrient which probably affect the decreased of dysmenorrhea pain. Moreover, the pain was a personal, subjective experience, influenced by learning, and other psychological variables, it could be biased in this study. Authors declared that there is no conflict of interest regarding of this article.

\footnotetext{
REFERENCE

Agostinis C, Zorzet S, De Leo R, Zauli G, De Seta F, Bulla R (2015). The combination of N-Acetyl cysteine, Alphalipoic acid, and bromelain shows high anti-inflammatory properties in novel in vivo and in vitro models of Endometriosis. Mediator of Inflammation, 2015: 1-9.

Al-Asadi JN, Abdul-Quadir RA (2013). Dysmenorrhoea and its impact on daily routine activities among secondary school students in Basra, Iraq. J Fac Med Baghdad, 55 : 339-344.

Ali BH, Blunden G, Tanira MO, Nemmar A (2008). Some phytochemical, pharmacological dan toxicological properties of ginger (Zingiber officinale
} 
Roscoe): a review of recent research. Food Chemical Toxicology, 46(2): 409-420.

Bernardi M, Lazzeri L, Perelli F, Reis FM, Petraglia F (2017). Dysmenorrhea and related disorders: Review. F10ooresearch, 6: 1-7.

Bhui K, Prasad S, George J, Shukla Y (2009). Bromelain inhibits COX-2 expression by blocking the activation of MAPK regulated NF-kappa B against skin tumor-initiation triggering mitochondrial death pathway. Cancer Lett, 282: 167-176.

Bolten WW, Glade MJ, Raum S, Ritz BW (2015). The safety and efficacy of an enzyme combination in managing knee osteoarthritis pain in adults: A randomized, double-blind, placebocontrolled trial. Arthritis, 25: 15-21.

Contreras A, Paape MJ, Miller RH, Corrales JC, Luengo C, Sanchez A (2008). Effect of bromelain on milk yield, milk composition, dan mammary health in dairy goats. Tropical Animal Health Production, 41: 493-498.

Chen CX, Barrett B, Hindawi KLK (2016). Efficacy of Oral Ginger (Zingiber officenale) for Dysmenorrhea: A Systematic Review and Meta-Analysis. Publishing Corporation EvidenceBased Complementary and Alternative Medicine, 57: 1-10.

Dighe NS, Pattan SR, Merekar AN, Laware RB, Bhawar SB, Nirmal SN, Gaware VM, Hole MB, Musmade DS (2010). Bromelain A Wonder Supplement: A Review. Pharmacologyonline, 1: 11-18. Dugasani S, Pichika MR, Nadarajah VD, Balijepalli MK, Tandra S, Korlakunta JN. 2010. Comparative antioxidant and anti-inflammatory effects of [6]gingerol, [8]-gingerol, [10]-gingerol and [6]-shogaol. Journal of Ethnopharmacology, 127: 515-520.
Fatima A, Mamatha KR, Ambika B, Rajarathna K (2017). Self-medication practice in primary dysmenorrhea among medical and paramedical students - A cross-sectional questionnaire study. National Journal of Physiology, Pharmacy and Pharmacology, 7(5): 458-463.

Hidayat R (2010). Efek analgesik dan antiinflamasi jus buah nanas (Ananas comosus) pada mencit betina galur swiss. Thesis. Sanata Dharma University, Yogyakarta.

Hirche C, Citterio A, Hoeksema H, Koller J, Lehner M, Martinez JR, Monstrey S, et al. (2017). Eschar removal by bromelain based enzymatic debridement (Nexobrid $囚)$ in burns: An European consensus. Burns, 17: 19-29.

Jayachandran S, Khobre P (2017). Efficacy of Bromelain along with Trypsin, Rutoside Trihydrate Enzymes dan Diclofenac Sodium Combination Therapy for the treatment of TMJ Osteoarthritis - A Randomised Clinical Trial. Journal of Clinical Diagnosis Respiratory, 11 (6): 9-11.

Jenabi E (2013). The effect of ginger for relieving of primary dysmenorrhea. Journal of the Pakistan Medical Association, 63 (1): 8-10.

Jung HW, Yoon CH, Park KM, Han HS, Park YK (2009). Hexane fraction of Zingiberis Rhizoma Crudus extract inhibits the production of nitric oxide and proinflammatory cytokines in LPS-stimulated $\mathrm{BV} 2$ microglial cells via the NF kappaB pathway. Food Chemical Toxicology, 47: 1190-1197.

Latha S, Venketesan L (2016). Effectiveness of Ginger tea on dysmenorrhea among college student. International Journal of Applied Research, 2 (12): 669-671. 
Leelavathi S, Hemavathy V (2015). Effectiveness of Ginger Remedy on Dysmenorrhea. International Journal of Innovative Research in Science, Engineering and Technology, 4 (5): 29042908.

Madhubala C, Jyoti K (2012). Relation between dysmenorrhea dan body mass index in adolescents with rural versus urban variation. The Journal of Obstetrics dan Gynecology of India, 62 (4): 442-445.

Mohamed SIA, Jantan I, Haque MA (2017). Naturally occurring immunomodulators with antitumor activity: An insight on their mechanisms of action. International Immunopharmacol, 50: 291-304

Muhammad ZA, Ahmad T (2017). Therapeutic uses of pineapple-extracted bromelain in surgical care-A review. J Pak Med Assoc, 67 (1) :121-125

Müller S, März R, Schmolz M, Drewelow B, Eschmann K, Meiser P (2013). Placebo-controlled randomized clinical trial on the immunemodulating activeties of low- and high-dose bromelain after oral administration - new evidence on the anti-inflammatory mode of action of bromelain. Phytotherapy Research, 27(2): 199-204.

Onken JE, Greer PK, Calingaert B, Hale LP (2008). Bromelain treatment decreases secretion of pro-inflammatory cytokines and chemokines by colon biopsies in vitro. Clinical Immunology, 126: 345-352.

Ozgoli G, Goli M, Moattar F (2009). Comparison of effects of ginger, mefenamic acid, dan ibuprofen. on pain in women with primary dysmenorrhea. Journal of Alternative dan Complementary Medicine, 15(2): 129-132.

Pan MH, Hsieh MC, Kuo JM, Lai CS, Wu H, Sang S (2008). [6]-Shogaol induces apoptosis in human colorectal carcinoma cells via ROS production, caspase activation, and GADD 153 expression. Molecular Nutrition and Food Research, 52: 527-537.

Pavan R, Jain S, Shraddha, Kumar A (2012). Properties and Therapeutic Application of Bromelain: A Review. Biotechnology Research International, $9: 203-208$

Rahnama P, Montazeri A, Huseini HF, Kianbakht S, Naseri M (2012). Effect of Zinger officinale R. rhizomes (ginger) on pain relief in primary dysmenorrhea: A placebo Randomized trial. BMC Complementary dan Alternative Medicine, 12(92): 1-8.

Ramya S, Vasundara K, Suvarna, Pundarikaksha HP, Prathap B, Gladius JH, et al (2014). A prospective study of the pattern of drug use in primary dysmenorrhoea in a tertiary care hospital. Int J Res Pharmacol Pharmacotherapy, 3(1): 80-84.

Rathnavelu V, Alitheen NB, Sohila S, Kanagesan S, Ramesh R (2016). Potential role of bromelain in clinical dan therapeutic applications (Review). Biomedical Reports, 5: 283-288.

Rodrigues S, Gomes W, Ferndanes FAN (2017). Effect of acoustically assisted treatments on vitamins, antioxidant activity, organic acids dan drying kinetics of pineapple. Ultrason Sonochem, 35: 92-102.

Sahbaz A, Aynioglu O, Isik H, Ozmen U, Cengil O, Gun BD, Gungorduk K (2015). Bromelain: A natural proteolytic for intra-abdominal adhesion prevention. International Journal of Surgery, 14: 7 - 11 .

Santoro NF, Neal-Perry G (2010). Amenorrhea: A case-Based, Clinical Guide Contemporary endocrinology. Spring- 
er Science Business Media LLC, Berlin.

Shirvani MA, Motahari-Tabari N, Alipour A (2014). Use of ginger versus stretching exercises for the treatment of primary dysmenorrhea: A Randomized controled trial. Journal of Integrative Medicine, 15 (4): 295-301.

Singh T, More V, Fatima U, Karpe T, Aleem MA, Prameela J (2016). Effect of proteolytic enzyme bromelain on pain and swelling after removal of third molars. Journal of International society of preventive and community dentistry, 6 (3): 197-204.

Sorice A, Guerriero E, Capone F, Colonna G, Castello G, Constantini S (2014). Ascorbic acid: Its role in Immune System and Chronic Inflammation Diseases. Mini-review in Medicinal Chemistry, 14 (5): 1-9.

Sowjanya K, Spandana U, Manjula RR, Havilah E, Sravani T, Shiva G, Nageswara, R (2016). Wound healing activity dan anti-ulcer activity of ethanolic extract of peels of Ananas comosus. European journal of pharmaceutical dan medical research, 3(3): 417-422.
Tadikonda A, Pentapati KC, Urala AS, Acharya S (2017). Anti-plaque dan anti-gingivitis effect of Papain, Bromelain, Miswak dan Neem containing dentifrice: A Randomized controlled trial. Journal Clinical Experimental Dental, 9(5): 649-653.

Tap FM, Majid FAA, Ismail HF, Wong TS, Shameli K, Miyake M, Khairudin NBA (2018). In Silico and In Vitro Study of the Bromelain-Phytochemical Complex Inhibition of Phospholipase A2 (Pla2). Molecules, 23 (73): 1-13.

Wallace S, Keightley A, Gie C (2010). Dysmenorrhoea. The Obstetrician \& Gynaecologist, 12 : 149-154.

Wong CL, Farquhar C, Roberts H, Proctor $M$ (2009). Oral contraceptive pill as treatment for primary dysmenorrhoea. Cochrane Database of Systematic Reviews, 7(4) : 1-10

Zhou Z, Wang L, Feng P, Yin L, Wang C, Zhi S, Dong J, et al. (2017). Inhibition of Epithelial TNF- $\alpha$ Receptors by Purified Fruit Bromelain Ameliorates Intestinal Inflammation and Barrier Dysfunction in Colitis. Frontiers in Immunology, 8: 1468-1474. 